\title{
The effect of merger announcements on the share prices of the acquired and acquiring companies
}

\author{
J.F. Affleck-Graves, T.P. Flach and A.S. Jacobson \\ School of Business, University of Cape Town, Private Bag, Rondebosch, 7700 Republic of South Africa
}

Accepted I May 1988

\begin{abstract}
In this paper the cumulative average residual (CAR) methodology is used to examine the effect merger announcements have on the returns earned by both the shareholders of the acquiring companies and the acquired companies. The results indicate that shareholders of the acquired companies earn significant positive abnormal returns in the ten weeks prior to the merger announcement. On the other hand, no evidence is found of positive abnormal returns accruing to the shareholders of the acquiring companies. Indeed, if anything, the abnormal returns are negatiuve for this group of shareholders. Finally empirical results are presented which indicate the effect on the CAR plots of different research methods. These results indicate that different CAR plots can be obtained from the different methods. However, these differences are not sufficient to alter the overall conclusions of the study.
\end{abstract}

\begin{abstract}
In hierdie artikel word die kumulatiewe gemiddelde abnormale opbrengs (CAR) metodologie gebruik om die effek van die aankondiging van samesmeltings van maatskappye op die opbrengste wat deur die aandeelhouers van albei die oornemende en oorgenome maatskappye verdien is, te ondersoek. Die resultate dui aan dat die aandeelhouers van die oorgenome maatskappye positiewe abnormale opbrengste verdien in die tien weke voor die samesmeltingsaankondiging. Daar is geen bewys dat positiewe abnormale opbrengste van die aandeelhouers van die oomemende maatskappye toeneem nie. Inderdaad, daar is bewys dat die abnormale opbrengste vir hierdie groep aandeelhouers wel negatief is. Ten slotte word empiriese resultate voorgelê wat die effek van die verskillende navorsingsmetodes op die CAR-grafieke aandui. Hierdie resultate dui aan dat verskillende CAR-grafieke behaal kan word deur die verskillende metodes te gebruik. Hicrdie afwykings is egter nie groot genoeg om die totale gevolgtrekkings te verander nie.
\end{abstract}

Correspondence address: G.D.I. Barr, Department of Mathematical Statistics, University of Cape Town, Rondebosch, 7700 Republic of South Africa

\section{Introduction}

Mergers and acquisitions have long played an important role in the growth of firms (Mandelker, 1974: 303) and recent years have seen increasing levels of merger activity in most developed countries. Numerous theories such as those of tax considerations, inefficient management of target companies and synergy have emerged as possible explainants of this increased merger activity. They all have one unifying thread however, namely that to be successful, mergers and acquisitions must increase the present value of the owners' interest in the firm (Hogarty, 1970: 317).

In recent years a vast literature on the subject of mergers and acquisitions has built-up. It is not the aim of this paper to summarize all aspects of such research or indeed to comment on the significance of such research. Rather, the authors will concentrate on the effect a merger announcement has on the share prices of the participating parties. For a fuller discussion of the literature the reader is referred to Copeland \& Weston (1983).

Assessment of the effects of mergers and acquistitions on the share prices of companies engaged in merger activity has been a source of considerable controversy among financial researchers for many years. In particular, studies undertaken overseas have focused on whether capital markets are efficient with respect to merger announcements, and whether any abnormal gains accrue to shareholders of acquiring and/or acquired companies. Studies such as those of Halpern
(1973), Mandelker (1974), Langetieg (1978) and Dodd (1980) all showed that shareholders of acquired companies enjoy significant positive abnormal gains on or before the announcement of the merger bid. Dodd (1980) and Asquith (1983) concluded that even when bids have been rejected, net shareholder gains are still positive.

The studies on acquiring firms provide conflicting evidence of the effects of mergers. Asquith (1983) and Schipper \& Thompson (1983) found that positive gains are made by acquiring firms which engage in announced merger programmes and that these gains are capitalized at the announcement of such prugrammes. In studies of individual mergers, however, such as those of Halpern (1973) and Mandelker (1974), there is no evidence of positive gains being made by shareholders of acquiring firms. Dodd (1980) in fact found evidence of small losses whether the merger bid is successful or not. Barnes (1984) extended this view and founds significant negative gains in the longer term.

In South Africa, little quantitative research has emerged attempting to examine merger activity on the JSE. Indeed, as Bhana (1984) noted, except for Macgregor (1979), the merger and acquisitions that took place during the 1960's and 1970's passed virtually undocumented. Certainly, few if any studies have emerged which examine the effects of merger activity on the share price of both the acquiring and the target company.

In this study therefore the effect of mergers on the 
share price performance of South African companies listed on the Johannesburg Stock Exchange (JSE) is examined. The objective is to assess whether firstly, mergers or acquisitions are associated with any abnormal positive or negative shareholder returns and if so, how these returns are shared between the sharcholders of acquiring and acquired companies; secondly, whether the JSE is efficient with respect to merger announcements. In addition the popular cumulative average residual (CAR) methodology is reviewed and three alternative models are used to obtain the CAR plots.

The following section discusses the selection of the sample and the data collection. Thereafter the methodology used in the study is described while the results are presented in the fourth section of the paper. Finally, a comparison of alternative CAR methodologies is presented and some areas for possible future research are identified.

\section{Data collection}

The JSE monthly bulletin for December, 1984 was used to identify mergers for inclusion in the study. The merger had to meet the following criteria to qualify for inclusion in the sample.

1. The effective date of the merger or acquisition had to be between November 1977 and January 1984 .

2. An attempt was made to select mergers in which the acquiring company had not engaged in more than one merger or acquisition within that particular year.

3. Both the acquiring and acquired companies had to be listed on the JSE for at least two years prior to the merger or acquisition and preference was given to companies for which four years of data were available.

On completion of the sample selection the date of the first public announcement of the merger was established. Thereafter the following information was collected for each company.

1. Weekly sector and market indices as well as share prices of both the acquiring and the acquired companies for the 52 weeks prior to the announcement date.

2. Weekly sector and market indices and weekly share prices of the acquiring company for the 52 weeks subsequent to the announcement date (the acquired company having been delisted on the effective date of the merger).

3. Monthly share prices, sector and market indices for the 36 months prior to the date of the data collected under (1) above.

The application of the fairly rigid selection criteria mentioned above, and the unavailability of suitable indices for a period of the study had the effect of restricting the sample to 25 mergers. These are listed in Appendix 1.

\section{Methodology}

Throughout the study all calculations were based on returns rather than on the raw price data. Thus all share prices and indices collected were converted to returns using the following formula:

$R_{t}=\left(\mathrm{P}_{\mathrm{t}}-\mathrm{P}_{\mathrm{t}-1}\right) / P_{t-1}$

where $R_{t}=$ Return on the share/index in period $t ; P_{t}=$ Price at time $t$; and $P_{t-1}=$ Price at time $t-1$.

Simple linear regression was then employed to determine the relationship between the shares and their respective indices, and the market. Three models were used to manipulate the data, namely the Market Model, the Industry (Halpern) Model and the 0-1 Model. All three models use the concept of 'residual analysis' which was developed by Fama, Fisher, Jensen \& Roll (1969) in a study conducted to ascertain the adjustment of stock prices to share splits.

The Market Model expressed in an expectations form can be written as:

$E R_{s}=A+B R_{m}$

where $E R_{s}=$ the expected return on the share; $A=$ the alpha (return expected when the market return is zero); $B=$ the well-known beta coefficient which measures the volatility of the share relative to the market; and $R_{m}=$ the return on the market index.

Estimation of the parameters $A$ and $B$ is a key step in the methodology and has received much attention in the recent finance literature. The traditional approach has been to use historic data on the share price and a market index in an ordinary least squares (OLS) regression so as to obtain the best linear unbiased estimates of both $A$ and $B(a$ and $b$ ). This approach was followed in this paper and the estimates $a$ and $b$ (of the parameters $A$ and $B$ ) were obtained using 36 months of historic data prior to the year preceding the merger announcment. This was done to avoid any biases that might occur in the estimation procedure due to speculation and leakages of information in the year preceding the merger announcement.

Having obtained the OLS estimates of $A$ and $B$, the expected returns on the share $(E R)$ were calculated for the 52 weeks prior to and after the announcement date of the merger by substituting the actual market return in each week into equation 1 . That is,

$E R_{i t}=a+b R_{M t}$

where $E R_{i t}=$ the expected return on share $i$ in week $t$; $R_{M t}=$ the actual return on the market in week $t$; and $a$ and $b$ are the OLS estimates of the parameters $A$ and $B$.

The JSE Actuaries Industrial Index was used as a surrogate for the market.

The abnormal return for each share was then calculated as

$A R_{i t}=R_{i t}-E R_{i t}$

where $A R_{i t}=$ the abnormal return on share $i$ in week $t$.

These residuals were then averaged across all 25 mergers for each of the 104 weeks ( 52 weeks prior to and 
52 weeks after the merger) and cumulated to obtain the cumulative average residual (CAR) series. Mathematically:

$$
C A R_{k}=\sum_{t=-52}^{k}\left(\sum_{i=t}^{25} A R_{i /} / n\right)
$$

where $C A R_{k}=$ cumulative abnormal return in week $k$; and $n=$ the number of mergers examined.

This describes the basic methodology used in this study to analyse the full set of 25 mergers.

As eight of the mergers included in the sample involved the acquiring company buying out the minority interest of its subsidiary, it was decided to examine these mergers and the remaining 17 'pure' mergers independently to check for the possibility of differing performance between the two groups. Hence the entire procedure was repeated for each of these subsets.

As mentioned previously, estimation of the $A$ and $B$ paramcters is a cause of some controversy in the finance literature, especially on thinly traded exchanges such as the JSE (Strebel, 1977). While attempts have been made to overcome the estimation problems (e.g. Dimson, 1979) they have not always proved satisfactory. To overcome these estimation problems, Brown \& Warner (1980) have suggested the use of a so-called naive or zero-based approach in which alpha is set equal to zero and beta equal to one. This obviates any estimation and in fact merely results in the abnormal return being calculated as the difference between the return on the share and the return on the market. Mathematically, this model can be expressed as follows

$A R_{i t}=R_{i t}-R_{m t}$

where all symbols are as previously defined. Once the $A R_{i t}$ series have been determined, the same CAR methodology defined above may be used.

Finally, the industry model suggested by Halpern (1973) was used. This model allows for adjustments for both market-wide and industry-specific movements. In using this model the following two-step estimation procedure was used.

Firstly, the expected return on the index was determined as follows

$E S_{i t}=C+D R_{m t}$

where $E S_{i t}=$ the expected return on sector $i$ in period $t$; and $C$ and $D$ are the intercept and slope parameters respectively.

As before $C$ and $D$ were estimated (by $c$ and $d$ ) using ordinary least squares regression. The abnormal return on the sector was then determined as

$A S_{j t}=S_{j t}-E S_{j t}$

where $A S_{j t}=$ the abnormal return on sector $j$ in period $t$; $S_{j t}=$ the actual return on sector $j$ in period $t$; and $E S_{j t}=c+d R_{m t}=$ the expected return on sector $j$ in period $t$ given the market return $R_{m}$ in period $t$.

This abnormal return on the sector was then used in the full industry model to estimate the expected return on the share as follows.

$E R_{i t}=B_{\mathrm{o}}+B_{1} R_{m t}+B_{2} A S_{j r}$

where $A S_{j t}=$ the abnormal return on sector $j$ (the sector in which share $i$ is quoted on the JSE) in period $t ; B_{0}, B_{1}$ and $B_{2}$ are the regression parameters; and all other symbols are as previously defined.

All of the share estimations were done on the 36 monthly returns prior the commencement of the year preceding the merger announcement. The JSE Actuaries Industrial and sector indices were used for the market and industries respectively.

Having estimated $B_{0}, B_{1}$ and $B_{2}$ (by $b_{0}, b_{1}$ and $b_{2}$ ) the abnormal return on each security was then computed for each of the 52 weeks preceding and following the merger announcement as follows:

$$
\begin{aligned}
A R_{i t} & =R_{i t}-E R_{i t} \\
& =R_{i t}-\left(b_{0}+b_{1} R_{m t}+b_{2} A S_{j t}\right)
\end{aligned}
$$

Once the $A R_{i t}$ series had been established, the same CAR methodology described previously was used.

\section{Results}

Figure 1 shows the plotted CARs for the market model using all 25 mergers. Examination of this figure indicates that the CARs for the acquiring companies remain relatively stable until approximatley 20 weeks following the merger after which there appears to be a steady downward drift. This indicates that shareholders of the acquiring companies earn negative abnormal returns in the year following the merger announcements.

Of particular interest are the periods immediately preceding and immediately following the merger announcement. From the CAR plot for the acquiring companies one can find no evidence of any positive abnormal returns accruing to these shareholders. Indeed, if anything, there is evidence of small negative

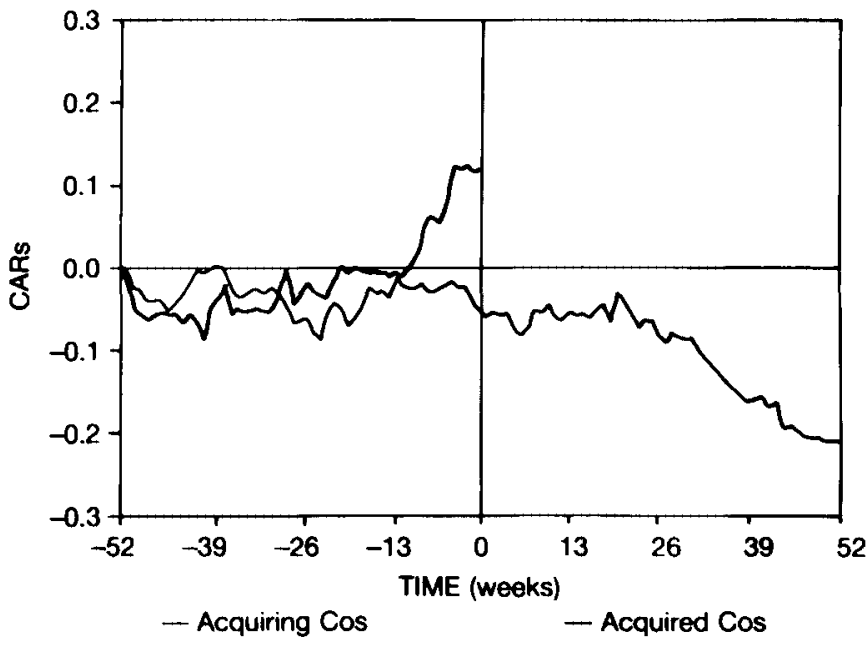

Figure 1 Market model; 25 mergers 
abnormal returns to the shareholders of these companies around the announcement date. However, the negative abnormal returns around the announcement date are not large and therefore it is concluded that merger announcements, on average. have no effect on the share prices of the acquiring companies. This in turn implies that such announcements have no information content for the market. This could arise for a number of valid reasons. For example, the market as a whole might have anticipated that the acquiring companies were likely to be involved in merger activity and this would already be impounded in the price of the shares. An announcement of the particular merger would merely confirm what the market had already anticipated and hence the announcement per se. would have no informational value to the market. Alternatively, the market might not anticipate the merger, but on the announcement it may assume that it was a zero net present value decision to the acquiring company, thereby leaving the price of the shares unchanged.

As regards the acquired companies. Figure 1 indicates that the CARs have a random pattern similar to that of the acquiring companies until approximately 13 weeks prior to the announcement. Thereafter, highly

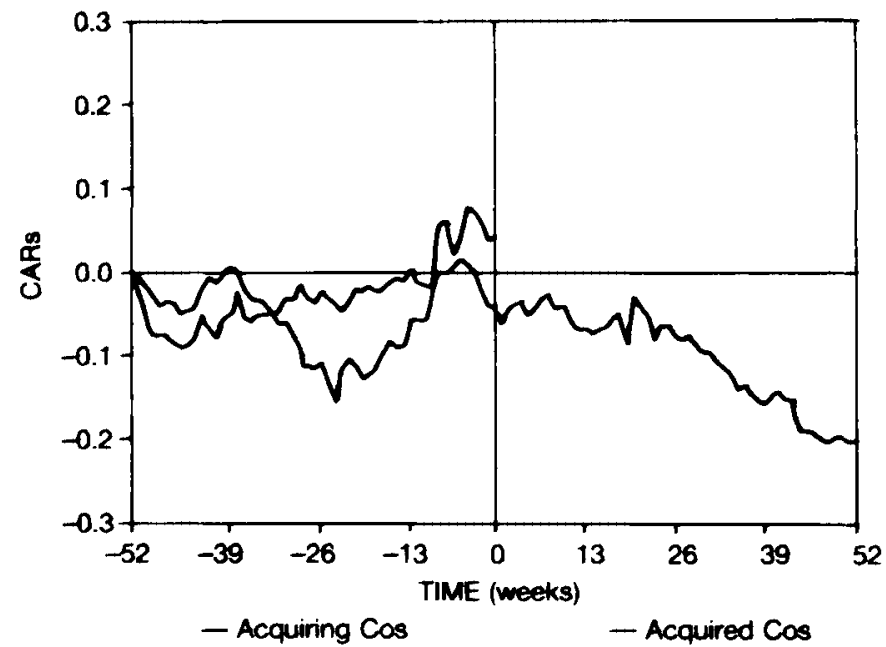

Figure 2 Market model; 17 mergers

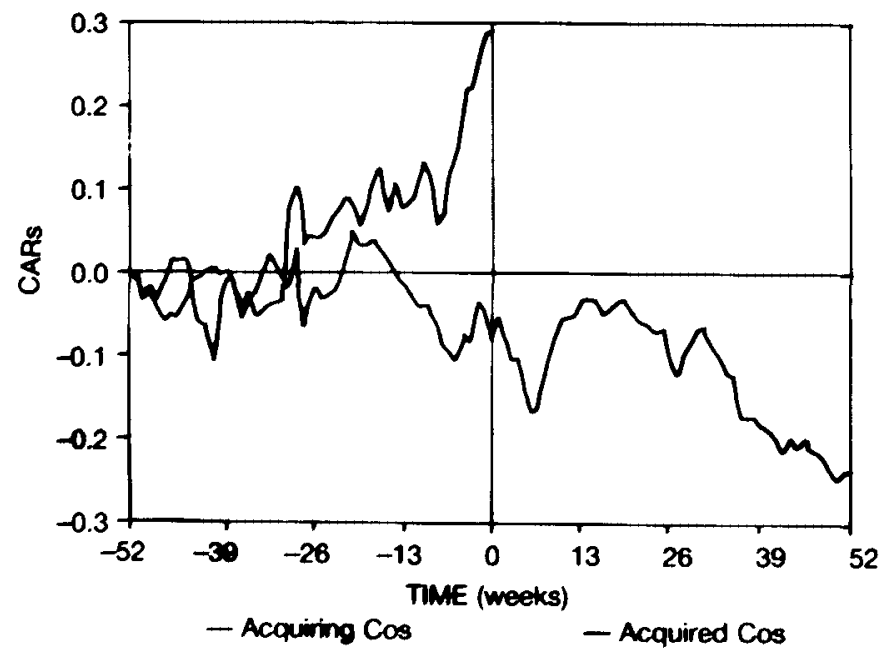

Figure 3 Market model; 8 mergers significant abnormal positive returns are earned by these shareholders with the CAR plot attaining a maximum value in the week of the announcement. This indicates that the shareholders of the acquired companies earn fairly substantial abnormal returns around the time of the merger announcement. In addition, the results presented in Figure 1 indicate that the information regarding the merger was already available in the market for approximately 13 weeks prior to its announcement.

The plotted CARs for the 17 'pure' mergers are displayed in Figure 2. The trend for the acquiring companies is similar to that displayed in Figure 1. The acquired companies also display a similar trend to that shown in Figure 1 with the CAR plot indicating positive abnormal gains for at least 13 weeks prior to the merger announcement.

The results for the eight 'buyout' mergers are displayed in Figure 3 and are not markedly different to those presented in Figures 1 and 2. The acquired companies in this group clearly achieved substantial positive abnormal returns in the eight weeks prior to the announcement although it is possible that the upward drift commenced some time before this. Also. in the case of the acquiring companies, it is possible that there is some evidence of a downward drift in the CAR plot both in the weeks preceding the week of the announcement and immediately thereafter. However, it must be remembered that this last case is based on only eight observations and hence greater variability must be expected in the CAR plot. It is thus concluded that Figures 2 and 3 confirm the results obtained in Figure 1.

It is therefore concluded that in the context of the JSE the empirical evidence indicates that shareholders of acquired companies earn abnormal returns for approximately 10 weeks prior to the announcement of the merger. On the other hand, there is no evidence of superior returns accruing to the shareholders of the acquiring companies either prior to or subsequent to the merger announcement. If anything, the abnormal returns are slightly negative for this group of shareholders around the time of the announcement.

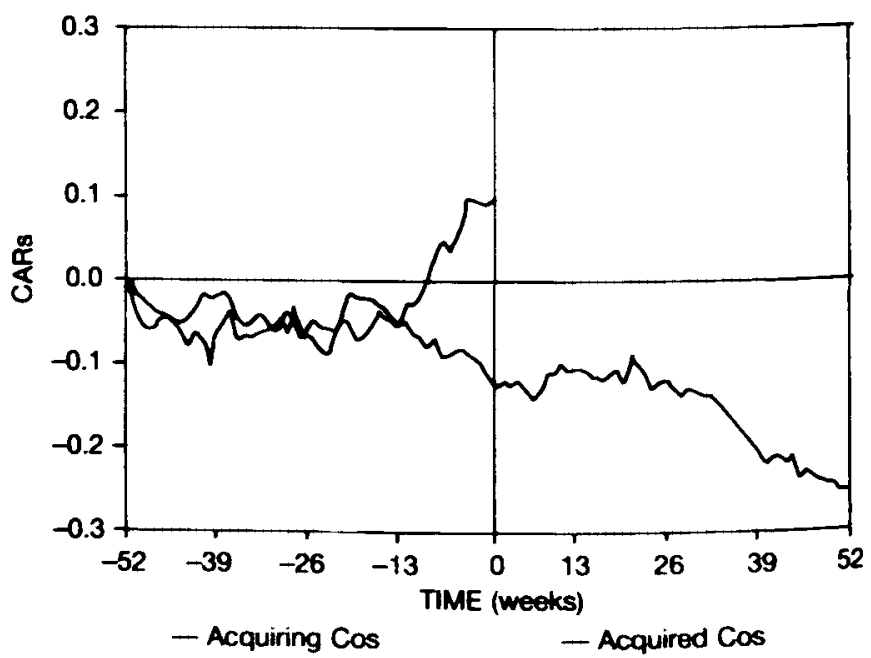

Figure 4 Industry model; 25 mergers 
Finally, the results indicate that this group of shareholders earn negative abnormal returns during the year following the announcement.

\section{Methodological considerations}

The results presented in the previous section were based on the plots obtained using the market model methodology. This was done as this methodology has been the most popular in the finance literature. As discussed in the section on methodology, two alternative methods of obtaining the CAR plots have been proposed in the literature, namely the industry model approach and the $0-1$ model approach.

In Figure 4, the CAR plots obtained using the industry model approach and all 25 mergers are presented. (Note that all plots are done on the same scale to facilitate comparison).

As can be seen from Figure 4 the results of the industry model are similar to those obtained using the market model, the only additional effects being a slight smoothing of the lines and an emphasis of the downward drift in the CAR plot of the acquiring companies prior to the merger announcement. This would indicate that using sector indices in conjunction with the market index does not significantly alter the interpretation of the results. This similarity can possibly be explained by the fact that the sector indices show a high degree of comovement with the market and is consistent with the absence of any significant 'industry' effects on the JSE as found by Visser \& Affleck-Graves (1983). In addition, it is interesting to note that even if industry effects were present, the cross-sectional aggregation in the market model would tend to remove any industry-specific factors provided the sample was large enough and spread across a wide cross-section of industries. In general therefore, the use of the industry model cannot be expected to significantly change the CAR plots obtained using the market model. For the sake of completion, the CAR plots for the 17 'pure' mergers and the eight 'buyout' mergers using the industry model approach are presented in Figures 7 and 8 of Appendix 2.

The final methodology examined in this section is that

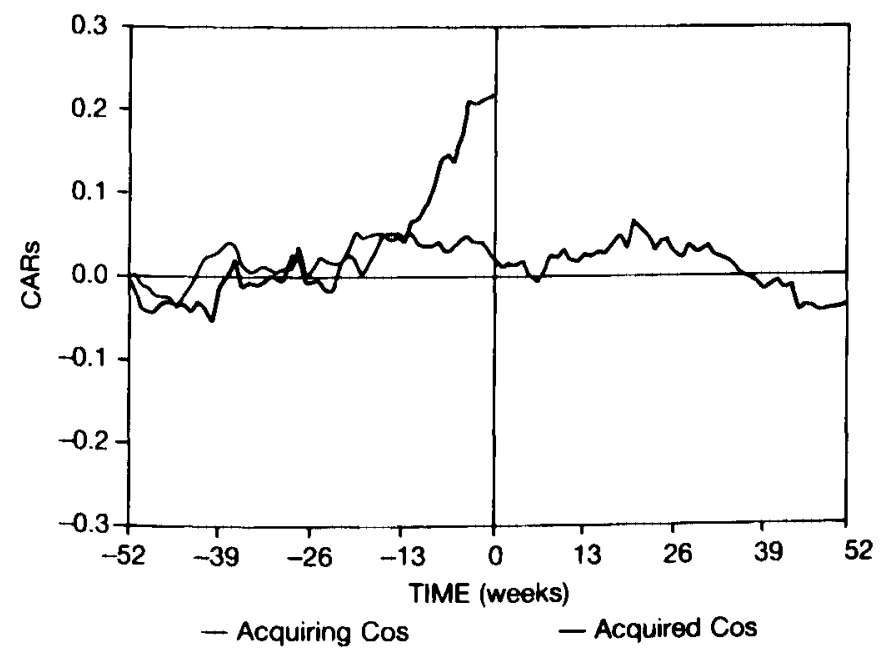

Figure $50-1$ model; 25 mergers of the 0-1 model approach. To examine this methodology the study was repeated for all 25 mergers using this model. The results are presented in Figure 5.

The CARs of the acquiring companies show no major trend throughout the period of the study, although there is some evidence of a downward drift commencing approximately 20 weeks after the announcement. A similar lack of trend is apparent for the acquired companies until approximately 13 weeks prior to the week of the announcement. Thereafter the returns become significantly positive indicating definite positive abnormal returns to the shareholders of the acquired companies in the period preceeding the announcement. This is exactly the same conclusion as that reached for the acquired companies using both the market model and industry model methodologies.

The CAR plots using the 0-1 model approach are presented for both the 17 'pure' mergers and the eight 'buyout' mergers in Appendix 2 (Figures 9 and 10). The results for these two cases are essentially the same as those presented in Figure 5 for the combined samples. Once again the results for the eight 'buyout' mergers appear to show some differences but these could be due to the small sample size and the possibility of thin trading in this group of companies.

In discussing the 0-1 methodology, it is worth pointing out that this approach results in adjusting the actual return on a company by deducting the return on the market. As such, it cannot be regarded as a risk adjustment. However, it must be pointed out that the CAR plot is in fact the plot of a portfolio's performance - a portfolio of all companies in that particular sample. Both finance theory and empirical research have suggested that portfolio alphas will be close to zero while portfolio betas will be close to one. Thus, unless the constituent stocks have a very different risk profile as a group, the alpha-zero beta-one approach can be theoretically justified.

In concluding this section on methodological implications, it is interesting to illustrate that the conclusions reached using the various methodologies are in fact identical for the 52 weeks preceeding the merger

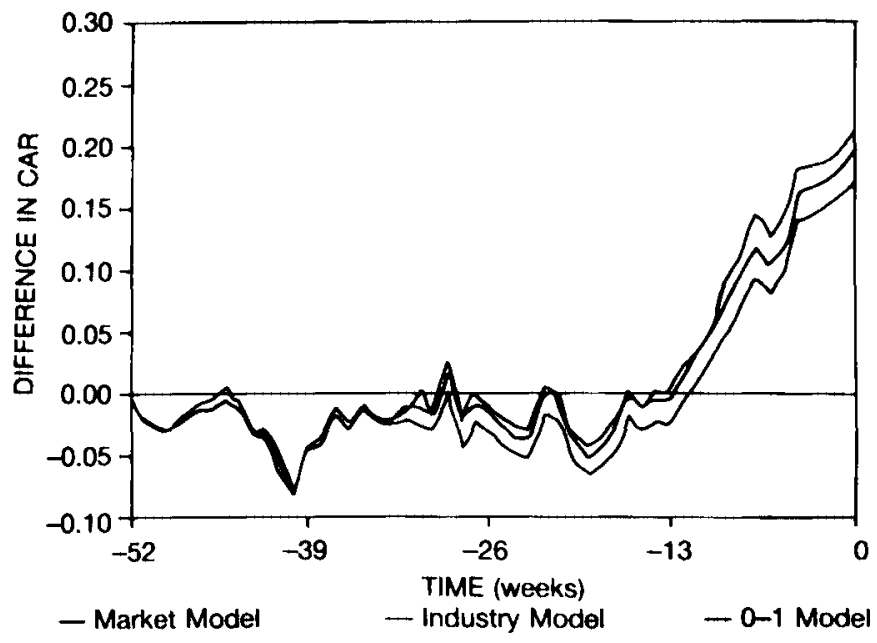

Figure 6 Model comparison; 25 mergers 
announcement. This can be done by looking at the series of differences in the two CAR series - that is, the series

$D_{t}=C A R_{a ; t}-C A R_{b ; t}$

where $C A R_{a ; t}$ is the CAR of the acquired companies in period $t$; and $C A R_{b ; r}$ is the $\mathrm{CAR}$ of the acquiring companies in period $t$.

The series of $D_{t}$ for the 52 weeks prior to the announcement week are shown in Figure 6 for all three models.

Figure 6 clearly demonstrates that the relative movement in the CAR of the acquired companies vis-à$v i s$ that of the acquring companies is almost identical for all three methodologies. This clearly illustrates that the conclusion of the relative implications of merger announcements are identical regardless of the model used.

In general therefore, the results presented in this section indicate that the overall conclusion that shareholders of the acquired companies gain from merger activity but that shareholders of the acquiring companies do not, is unaffected by the choice of methodology. However, it is also important to stress that the three methodologies do not produce identical plots. In particular, the three methodologies produce somewhat different plots in the case of the acquiring companies. While all three do indicate some degree of negative performance in the year following the announcement this is much stronger in the case of the industry model plot than in the case of the 0-1 model. In addition, the industry model plot indicates the negative drift at a much earlier stage (from approximately 20 weeks prior to the merger announcement) than in the case of either the market model or the 0-1 model.

As the industry model must (theoretically) be at least as good as the market model which in turn must be at least as good as the $0-1$ model. Figure 4 should be viewed as the most appropriate diagram for examining the effects of merger activity for companies listed on the JSE. However, the results clearly indicate that use of either the market model or the $0-1$ model would not greatly distort the results. Indeed, the existence of differences in the three series of plots are probably due to the samll sample size and should larger samples have been used it is likely that the differences in the results obtained using the three methodologies would have been even smaller.

\section{Conclusion}

Three significant features emerge from the empirical results presented above. Firstly, it is apparent from all the models used, that shareholders of the acquired companies experience abnormal positive returns immediately prior to the announcement date. These results are consistent with results from the NYSE (e.g. Halpern, 1973; Mandelker, 1974 and Langetieg, 1978). In addition, the results presented in this study indicate that the gains to the acquired companies appear to have been experienced from approximately 10 weeks prior to the announcement, whereas Mandelker (1974) and Langetieg (1978) observed the gains from 7 and 6 months respectively. In contrast Dodd (1980) using daily data, observed most of the gains accruing on the day before the announcement. The reason why the acquired companies experienced such gains on the JSE prior to the merger announcement is an issue requiring additional research. While one is tempted to conclude that insider trading or information leakages are the cause it is important to stress that this is in no way proved by the results presented above. Other rational explanations such as accurate appraisal by investment analysts and anticipation by the market cannot be ruled out.

Secondly, the study appears to indicate that shareholders of the acquiring companies do not benefit by the merger activity in the short term. This has also been observed by the researchers mentioned above. However, it should be noted that Schipper \& Thompson (1983) did observe some benefit to the shareholders of acquiring companies while a downward trend in the long term in the CARs of acquiring companies has also been reported previously (Hogarty, 1970; Barnes, 1984 and Asquith, 1983). This has been attributed to mergers, on average, being unsuccessful in the longer term. The results of this study indicate that the benefit to shareholders of the acquiring companies is unlikely to be positive and moreover, that, on average, the actual announcement of a merger has little impact on the share price of the acquiring company. Unfortunately the tests presented in this paper are not sufficiently powerful to enable a conclusion to be drawn as to why there is no impact on announcement nor as to why the subsequent returns are negative to the shareholders of the acquired companies. These are clearly areas requiring additional research.

Thirdly, the study provides some guidelines which may be useful to other researchers doing informationrelated studies on the JSE. The empirical results presented clearly indicate that the methodology used does effect the susbequent CAR plot. However, even in the case of a relatively small sample size (25) the overall conclusions are identical. Nevertheless, for researchers working with small sample sizes the results of this paper indicate that the industry model should be used to obtain the CAR plot. It is suggested therefore that more emphasis be given to this model in JSE based studies unless the sample size is large.

\section{Acknowledgement}

The authors wish to acknowledge the financial assistance rendered by the Human Research Council (HSRC) towards the cost of this research. Opinions expressed and conclusions arrived at are those of the authors and are not to be regarded as those of the HSRC.

\section{References}

Asquith, P. 1983. The Gains to Bidding Firms from Merger. $J$.

Finan. Econ, vol.11, 121-139. 
Barnes, F.A. 1984. The Effect of a Merger on the Share Price of the Attacker, Revisited. Account. Bus. Res., vol.57, $45-49$.

Bhana, N. 1984. The Long Term Effects of Takeovers on the South African Economy. S. Afr. J. Bus. Mgmt., vol.15, 229-231.

Brown, S.J. \& Warner, J.B. 1980. Measuring Security Price Performance. J. Finan. Econ, vol.8, 205-258.

Copeland, T.E. \& Weston, J.F. 1983. Financial Theory and Corporate Policy. 2nd Edition. U.S.A.: Addison-Wesley Publishing Company Inc.

Dimson, E. 1979. Risk Measurements When Shares are Subject to Infrequent Trading. J. Finan. Econ., vol.7, 197-226.

Dodd, P. 1980. Merger Proposals, Management Discretion and Stockholder Wealth. J. Finan. Econ., vol.8, 105-137.

Fama, E.F., Fisher, L., Jensen, M. \& Roll, R. 1969. The Adjustment of Stock Prices to New Information. Intern. Econ. Rev., vol.10, 1-21.

Halpern, P.J. 1973. Empirical Estimates of the Amount and Distribution of Gains to Companies in Mergers. J. Bus., vol.46, 554-575.

Hogarty, T.F. 1970. The Profitability of Corporate Mergers. J. Bus., vol.43, 317-327.

Langetieg, T.C. 1978. An Application of the Three-Factor Performance Index to Measure Stockholder Gains from Merger. J. Finan. Econ., vol.6, 365-383.

Mandelker, G. 1974. Risk and Return: The Case of Merging Firms. J. Fin. Econ., vol.1, 303-335.

MacGrcgor, I.H. 1979. Mergers, Acquisitions and Sharehodlers. Cape Town: Jutas. 165p.

Schipper, K. \& Thompson, R. 1983. Evidence on the Capitalized Value of Merger Activity for Acquiring Firms. J. Finan. Econ., vol.11, 85-119.

Strebel, P.J. 1977. The Limited Efficiency of the Johannesburg Stock Exchange. Investm. Anal. J., vol.10, 15-20.

Visser, F. \& Affleck-Graves, J. 1983. An Analysis of the Comovement of Shares Listed on the JSE. J. Stud. Econ. Econometrics, vol.17, 28-49.

\section{Appendix 1 Companies chosen for the sample}

\begin{tabular}{ll}
\hline Acquiring company & Acquired company \\
\hline Dorbyl Ltd & Busaf Industrics Ltd \\
Rembrandt Group Ltd & Oudemeester Ltd \\
Federale Foods Ltd & Simba Quix Ltd \\
Sam Steele Holdings Ltd & Steel and Barnett Ltd \\
C G Smith Sugar Ltd & Illovo Sugar Estates Ltd \\
Darling and Hodgson Ltd & Group Five Engineering Ltd \\
CNA Investments Ltd & Galio (Africa) Ltd \\
General Mining Union & Television and Electrical \\
\multicolumn{1}{c}{ Corporation } & Holdings Ltd \\
Kohler Ltd & DRG SA Ltd \\
The Tongaat Group Ltd & Hebotex Textiles Ltd \\
Tongaat Corogroup Ltd & Coronation Brick Free State Ltd \\
Transvaal Rand and Exploration & Rand Mines Properties Ltd \\
Co Ltd &
\end{tabular}

Appendix 1 Continued

\begin{tabular}{|c|c|}
\hline Acquiring company & Acquired company \\
\hline $\begin{array}{l}\text { Nampak Ltd } \\
\text { Metal Box South Africa Ltd }\end{array}$ & $\begin{array}{l}\text { Premier Paper Ltd } \\
\text { Metal Rolling and Tube Company } \\
\text { Holdings Ltd }\end{array}$ \\
\hline $\begin{array}{l}\text { Anglo American Properties Ltd } \\
\text { Woolworths Holdings Ltd }\end{array}$ & $\begin{array}{l}\text { Sorec Ltd } \\
\text { Truworths Ltd }\end{array}$ \\
\hline $\begin{array}{l}\text { Dunswart Iron and Steel Works } \\
\text { Ltd }\end{array}$ & Alpha Free State Holding Ltd \\
\hline U C Investments Ltd & Sentrust Ltd \\
\hline Amalgamated Retail Ltd & Melody Holdings Ltd \\
\hline Amalgamated Retail Ltd & ABC Corporation Ltd \\
\hline Metkor Investments Ltd & Hart Lid \\
\hline Metkor Investments Ltd & Wispeco Ltd \\
\hline Seardel Investment Corp Ltd & Desiree International Ltd \\
\hline Seardel Investment Corp Ltd & Dugson Ltd \\
\hline Seardel Investment Corp Ltd & Dubin Investment Ltd \\
\hline
\end{tabular}

\section{Appendix 2}

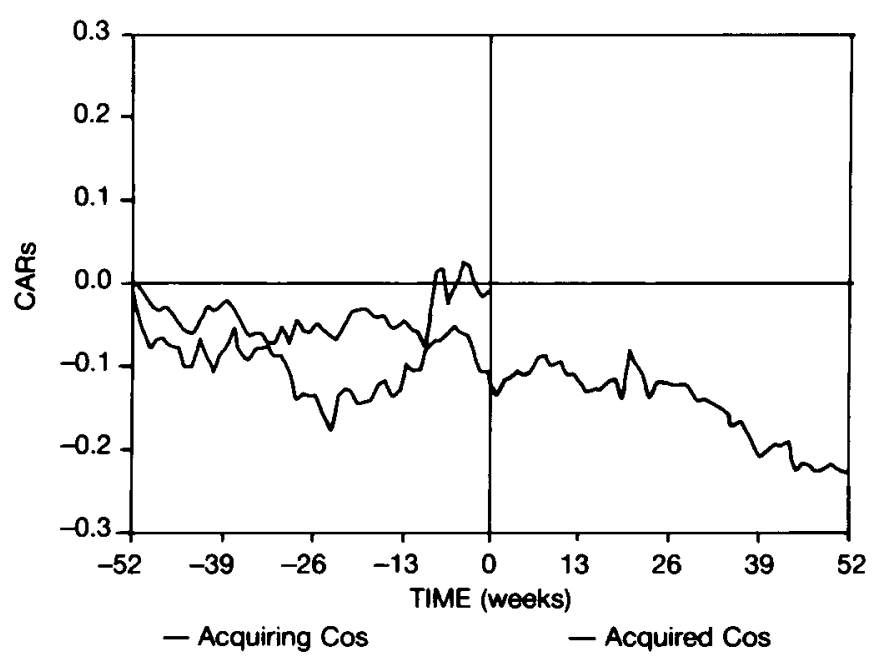

Figure 7 Industry model; 17 mergers

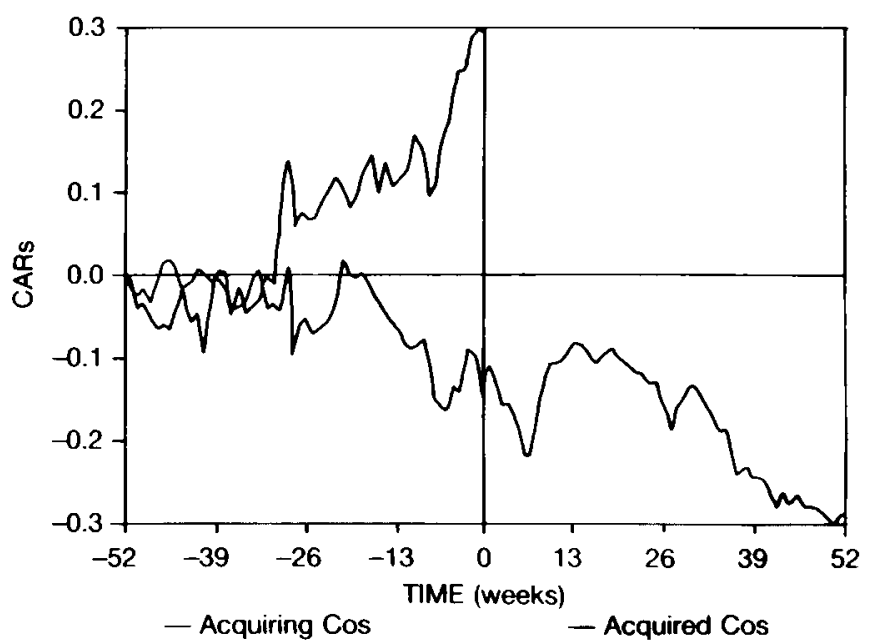

Figure 8 Industry model; 8 mergers 


\section{Appendix 2 Continued}

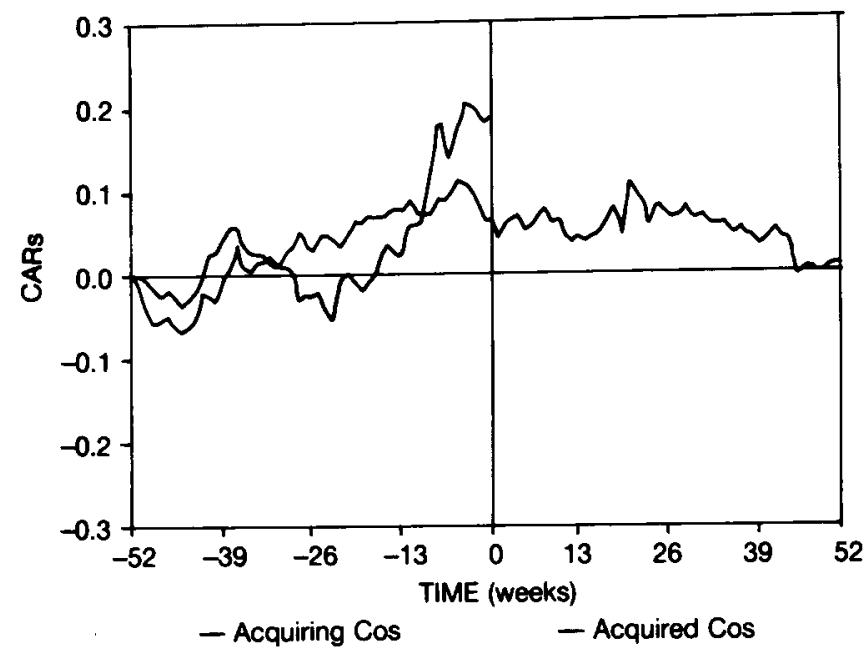

Figure $90-1$ model; 17 mergers

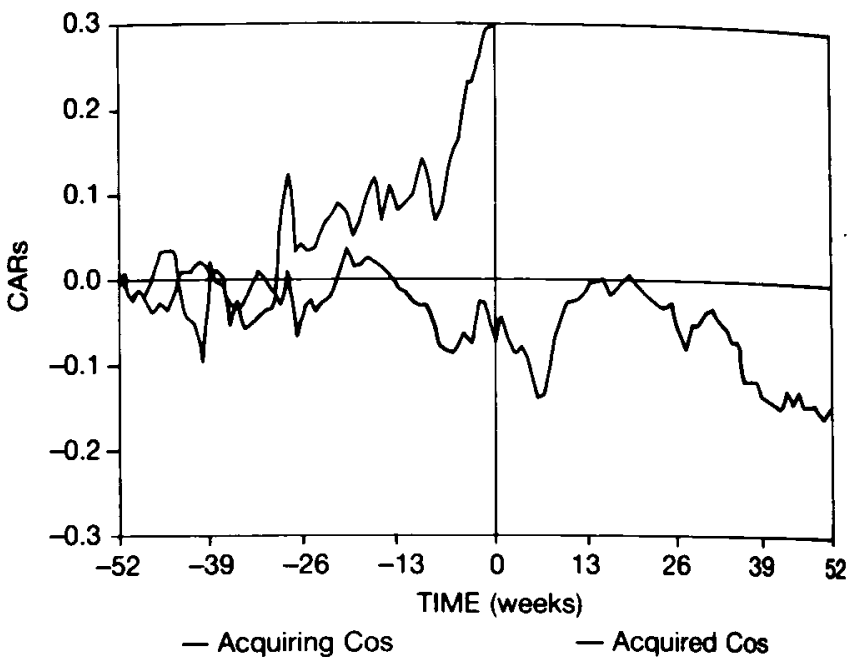

Figure $100-1$ model; 8 mergers 